\title{
Integrating Sustainability in Business: An Essential Need in the Global Context
}

\author{
Carmen Valentina Radulescu ${ }^{1}$, Loredana Popescu ${ }^{2}$, Carmen Georgiana Badea ${ }^{3}$
}

\begin{abstract}
In the context of globalization and sustainable development requirements reconfigures all aspects of social and economic life so as to remove disincentives for progress towards a society that recognizes the importance of capitalization not only economically but also in terms of human resources and natural resources. We started this research building on the general and specific trends identified as being relevant for integrating business sustainability: increasing inequality in revenue; decoupling economic growth from the opportunity to generate income through job creation, endangering the primary distribution of well-being; intensifying geostrategic competition; increasing pollution in developing countries; the manifestation of the impact of climate change through extreme weather phenomena and the diminution of water resources; increasing companies' contribution to addressing general development issues and increasing consumer demand for sustainable performance. In this context, I start with addressing and clarifying the concept of sustainable business, which is becoming more and more individualized in the global economy, its promotion and development becoming a flagship feature for many companies and I will continue with identifying and analyzing managerial strategies and tools.
\end{abstract}

Keywords: sustainable development; sustainability strategies; business; innovation.

\section{Introduction}

In the context of globalization and sustainable development requirements reconfigures all aspects of social and economic life so as to remove disincentives for progress towards a society that recognizes the importance of capitalization not only economically but also in terms of human resources and natural resources.

We started this research building on the general and specific trends identified as being relevant for integrating business sustainability: increasing inequality in revenue; decoupling economic growth from the opportunity to generate income through job creation, endangering the primary distribution of well-being; intensifying geostrategic competition; increasing pollution in developing countries; the manifestation of the impact of climate change through extreme weather phenomena and the diminution of water resources; stepping up action to combat climate change; increasing companies' contribution to addressing general development issues and increasing consumer demand for sustainable performance.

In this context, the challenge of finding solutions to development gaps and conflicts between human activities and natural systems has been supported by many researchers, scientific results constituting itself into a very rich knowledge base which is pointed out by policy Global Sustainable Development.

\footnotetext{
| ${ }^{1}$ Associate Professor PhD, The Bucharest University of Economic Studies

| ${ }^{2}$ Lecturer $\mathrm{PhD}$, The Bucharest University of Economic Studies

| $3 \mathrm{PhD}$ Candidate, The Bucharest University of Economic Studies
} 
Globalization is a complex process that continued to intensify over the last decades. Although similar forms of economic, social and political interactions have been identified and described for different historical stages, the contemporary process is set apart from others by the importance of the economic dimension - amplified by modern information and communication technologies. In this context, the influence of multinational companies has increased significantly.

The business environment is the sensory exponent of the economy, where macroeconomic and global trends are constantly scrutinized with a view to gaining a competitive edge. The focus on sustainable development, increasingly promoted at the declarative level, especially through regulations, standards and instruments based on the market mechanism (environmental taxes, negotiable pollution permits, etc.) did not go unnoticed, thus that more and more enterprises have adapted their mission and values to the new requirements (Bran et all, 2013).

Businesses create added value by using the natural resources they convert, a process in which they also generate pollution. Changing how they add value will therefore also help reduce pollution, thus contributing to the goals of sustainable development.

In this context, I start with addressing and clarifying the concept of sustainable business, which is becoming more and more individualized in the global economy, its promotion and development becoming a flagship feature for many companies. Sustainability is a major concern for an increasing number of businesses, their group of well-established, multinational companies operating in areas ranging from communications to mineral resource exploitation.

In order to meet the challenge of sustainable development, the business environment will have to consider changes in the following aspects (WBCSD, 2010):

- Accepting the constraints and opportunities of a world with limited natural resources that will soon be populated by 9 billion inhabitants;

- Redefining success and progress at national, company and individual level;

- Increasing bioproductivity;

- Creating solutions with low ecological impact that maintain quality of life in developed countries with an unacceptably high ecological footprint;

- Improve human development in developing countries without increasing the environmental footprint beyond acceptable limits.

In this context, I will continue with identifying and analyzing managerial strategies and tools that integrate business sustainability.

The particular configuration of internal and external factors restricts each company's ability to integrate sustainability so that a decision is made on the most appropriate way of integrating sustainability, namely choosing the most appropriate sustainability strategy. The correlation of the sustainability strategy with the business strategy provides the simplest, and most commonly used, typology. Thus, the risk avoidance strategy is differentiated; efficiency strategy (cost savings by increasing the efficiency of materials and energy use) and differentiation strategy. Each of these strategies involves innovation, but the importance of innovation for the success of the strategy is different. The first two categories pursue the same objective, minimizing costs, while the third uses sustainability as a means of differentiation.

Sustainable business management is not significantly different from business 
administration in general. One of the most important challenges, however, is to demonstrate through quantitative information how every action directed towards sustainability brings profit to company.

\section{Literature Review}

Speciality literature regarding sustainability integration in business is very extensive and diversified. Thus, the economic research fully reflects the importance of businesses for sustainable development, the last decades bringing an unprecedented growth of knowledge in this field. The variety of approaches, continuous growth of processed empirical data's volume and diversity, the multitude of analysis models that were elaborated and applied, the fastness of results integration in global and governmental policy making, but also in business plans are the main features that impose this field.

The process of sustainable development in that resource exploitation, investment directing, orientation of technological development and institutional change are in concordance with the present and future needs, is unavoidable. Since the proposal of the sustainable development concept it was stressed that the process is not easy, being necessary difficult decisions (Brundtland et all, 1987). This restrain was confirmed at more than two decades since the publication of the Brundtland Report by noticing the fact that in the opinion of company directors increasing environmental performance will lead to loss of competitiveness due to supplementary costs that does not generate immediate financial benefits. Consequently, the integration of sustainability in business strategies is not made in necessary path (Nidumolu et all, 2009).

For surprising the numerous new aspects that needed a conceptual approach in the research of sustainability from the entrepreneurial perspective there were formulated a number of notions for that the significance was established broadly, but which continue to undergo a process of increasing rigor, such as: sustainable business, green business, environmental business, responsible business, social business, sustainable value, environmental value, social value, (sustainable) business model etc.

The sustainable business is defined as the business in that there are accepted more perspective in defining value, the business securing the creation of economic value, social value, and environmental value (Mustață et all, 2013), respectively a business that is resilient against economic, social, and environmental changes (Moore and Manring, 2009). It is characteristic assuming commitments that address the goals of sustainable development such as social protection, education, eco-efficiency, eco-innovation, nature preservation etc. by using the triple bottom line (people, planet, profit).

Taking in account the fact that businesses are at the beginning of up taking sustainability, we consider relevant also the definition according to that the sustainable business is the business that creates for itself a competitive advantage by providing high value for customers while contributing to the sustainable development of the company and of the society (Ludeke-Freund, 2010). This definition emphasizes an advantage that could be temporary, respectively the first comers' advantage. Nevertheless, if we take in account the fact that this advantage could be valid for a long period of time its importance could not be neglected. 
Several decades ago the concept of sustainable business would be considered an oxymoron, since businesses were coined as the main cause for deepening social inequalities and for the degradation of the natural environment. Hence, the business could not be sustainable because of intrinsic characteristics that situate it on opposite position in relation with the goals of sustainable development. The pursuit of profit maximization, accomplished by the reduction of unproductive expenses and the importance of meeting short term financial goals are most frequently cited for illustrating the incompatibility between businesses and sustainable development (Globescan, 2012). Besides, the recognition of this incompatibility is proven the major importance granted for regulations in the first stages of environmental policy implementation, meaning the acknowledgment of the market failure situation or of the inability of businesses in generating solutions for the reduction of pollution of social issues (Bran et all, 2011).

By the consolidation of our understanding for the significance of sustainable development, but also under the influence of neoliberal orientation the need of entrepreneurial approach of society's problems emerged and businesses were recognized as one of the most important actors, which instead of limiting their selves to complying with legal provisions should be responsible for the integration of sustainable development's goals in the business strategy (Robèrt et all, 2002). In its essence sustainable business is the concept by that it is transposed in entrepreneurial terms a basic condition of sustainable development, namely the simultaneous progress on economic, social, and environmental plans (Rojanschi et all, 2006).

Concepts that are related and many times used as synonyms are "green business" or "responsible business". The sustainable business is confused with "green business" because in numerous studies the significance of the attribute "sustainable" is represented by the reduction of the ecological impact. Nevertheless, "green business" cannot be considered a genuine concept, being rather a formula by that businesses are expressing the care for the environment. In other words, it is the trade variation for environmental management that is assumed and implemented within an enterprise. Besides this understanding "green businesses" are considered also the businesses from sectors with positive environmental impact (for example, organic agriculture, forestry, ecotourism etc.), being the entrepreneurial correspondent for green economy. „Responsible business" is a notion by that are designated businesses that have corporate social responsibility programs (CSR). Although the CSR program also supposes the reduction of environmental impact, the notion of "responsible business" emphasises the contribution in solving some social issues.

The concept of "environmental business" although could be easily confused with the one of "green business" has a quite precise significance, being the business that occurs in the field of eco-industries, respectively activities that produce goods and services for measuring, preventing, limiting, minimizing and correcting water, air, and soil degradation, such as the ones related with waste, noise, and ecosystems. These comprise technologies, products, and services that reduce environmental risks and minimize pollution (Bilsen, Rademaekers, 2009).

"Social business" is the business that covers its costs while the profit is transferred to customers that benefit from lower prices and adequate service. It has no loss, does not pay dividends, it supports itself by selling products and services and reimburse 
investments (Yunus, 2010). The goal of social businesses is to serve society and to improve the status of poor. The components of the social business model are presented in figure 2.

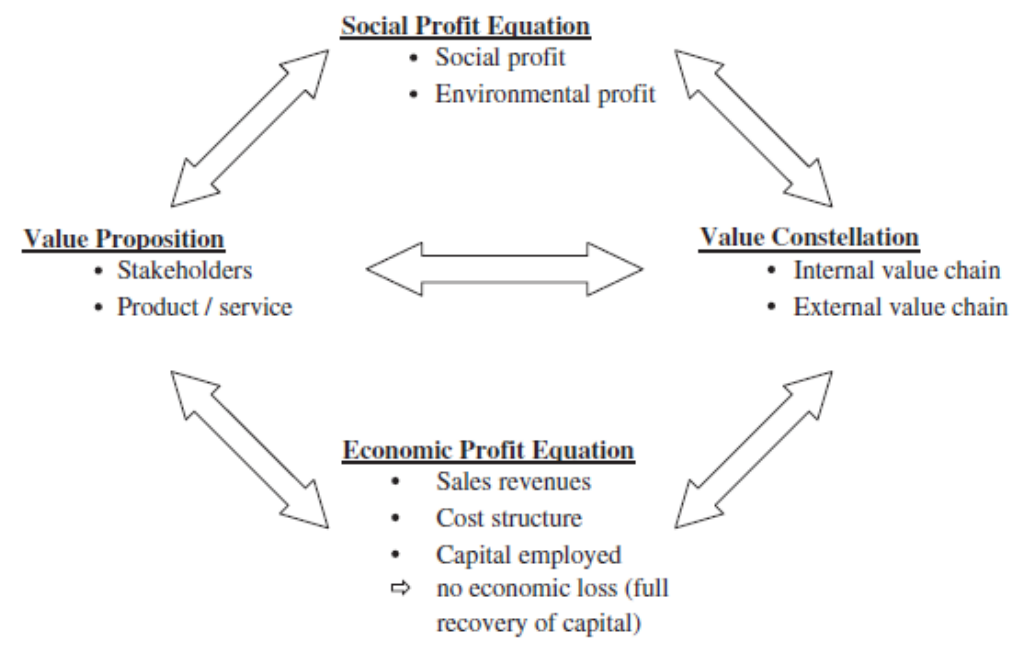

Figure 1: The components of the social business model

Source: Yunus, M., Moingeon, B., Lehmann-Ortega, L. (2010). Building social business models: lessons from the Grameen experience. Long range planning, 43(2): 308-325.

Plurality in the interpretation of the value concept is one of the most important characteristic that differentiates the sustainable business from the regular businesses. Ultimately, sustainable businesses supposes rethinking of the value proposition provided by the product or service, this process being deployed by adding new plans for assessment (social and environmental, besides the economic one), but also of new "users", respectively stakeholders (not only customers or consumers) (Bocken et all, 2013). In other terms, sustainable business is the business that creates sustainable value.

The sustainable value is based on a holistic vision that comprises economic, social, and environmental benefits and costs for all stakeholders, not only for consumers and customers. Thus, besides them, it will be taken in account the value proposition that could be identified by investors and shareholders, employees, suppliers, and partners. This supposes understanding the tangible and intangible value chains for identifying relations, exchanges and interaction and opportunities for collaboration (Allee, V. E. R. N. A., Schwabe, 2011).

For highlighting how the sustainable value is created there were proposed more models, more or less tributary to the models used for the analysis of businesses in general.

Sustainable value model presented in figure 3 shows that the values is created externally and on short term by improving reputation and providing legitimacy in relation to main stakeholders, while on long term by inscribing on an upward trajectory due to identification of new needs to be manifested in the context of sustainable development. 


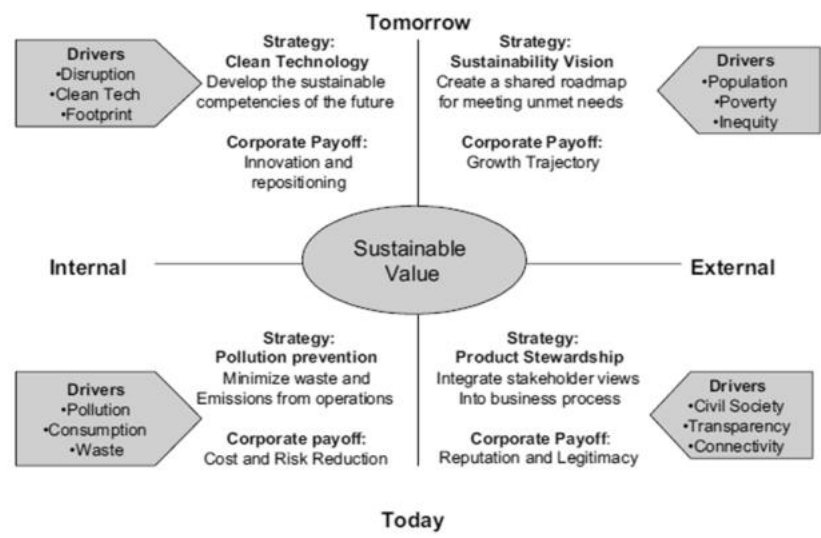

Figure 2: The matrix of sustainable value

Source: Hart, S., Milstein, M. (2003). Creating sustainable value. Academy of Management Executive, 17(2): 56-67.

Another model of sustainable value was proposed departing from the so called "premium profit" (figure 4). This is the profit obtained by the company by the particular allocation of certain resources. For instance, the profit obtained due to environmental management or adoption of social responsibility programs.

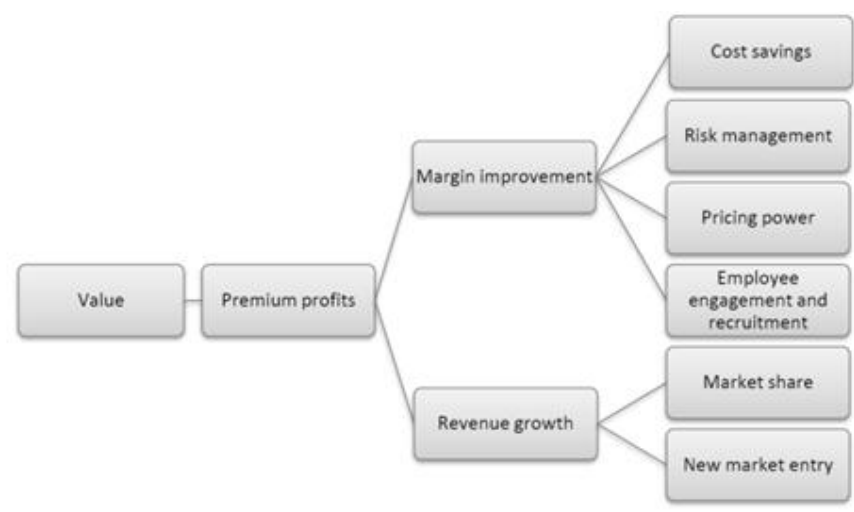

Figure 3: The model of sustainable value based on premium profit

Source: Dalbol, J.P., Dalbol, M.L., 2011. Sustainability and value creation. Changing the perception of environmental responsibility and economic benefits. Master Thesis, Copenhagen Business School.

In the attempt of highlighting the possibility of innovation to contribute to sustainable value creation it was proposed the model from figure 5. According to this, the value proposition represents the benefits provided for stakeholders and this should be approached from four perspectives: customer; other actors that interact with the enterprise; environmental and social impact. For each them it could be identified the current value proposition; the omitted, destroyed or lost value; and the opportunities for creating new value by new activities and relations. 


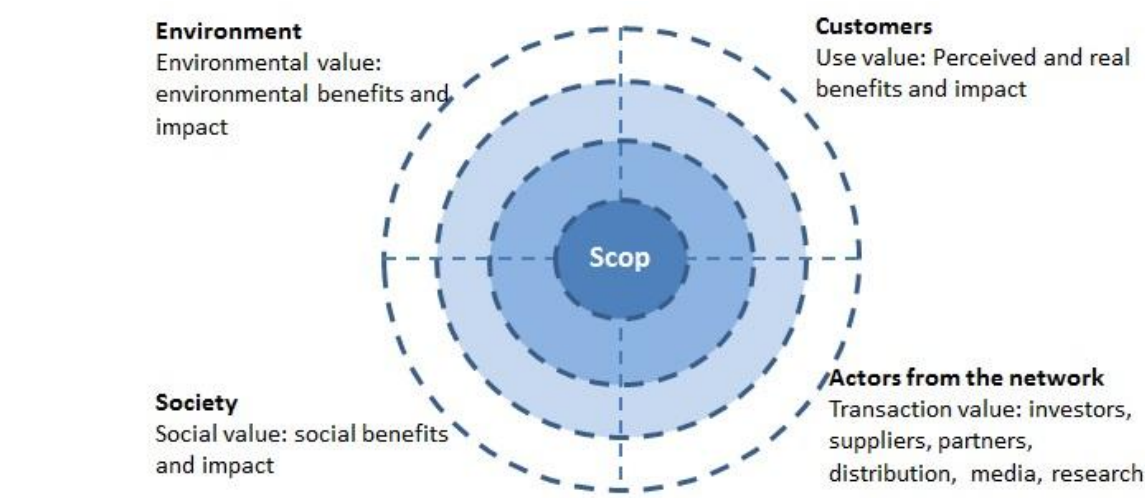

Captured value: current value proposition

( Omited, destroyed or lost value: negative results or not anough captured value from current activities

( Opportunities: new opportunities for creation and capturing of supplementary value by new activities and relations

Figure 4: Sustainable value mapping

Source: Bocken, N., Short, S., Rana, P., Evans, S. (2013). A value mapping tool for sustainable business modelling. Corporate Governance, 13(5): 482-497.

The destroyed value manifests in environmental degradation and negative social impact of the business representing in fact the negative externalities of the activity. The lost value occurs in situations than assets are not use appropriately, and materials and raw material are wasted, including by high rates of pollution. The opportunities for new value creation result from passing through the following stages (Bocken et all, 2013):

- Generating solutions for creating new value by reducing or eliminating destroyed value;

- Capturing lost value by new activities and relations;

- Reconceptualization of destroyed value as lost value.

The concepts of social value and environmental value are used for designating social, respectively environmental benefits. Social value means a contribution to any of the three values of development, namely self-support, self-esteem, and liberation from servitude (Sinkovics et all, 2014). Similarly, environmental value means a contribution to the reduction of environmental issues such as pollution, exhaustion of natural resources, loss of biodiversity etc.

The major changes supposed by transforming businesses to respond the requirements of sustainable development revealed the need of using the concept of business model, concept emerging along with the development of modern information and communication technology.

For the existing enterprises it is relatively simply to identify these components. For the new ones, the business model is used as a plan that specifies how profit is made. In relation with innovation, the business model is considered and intermediary element that allow the interaction among the ones involved in innovation (companies, financing bodies, research institutes etc.). The emergence of the concept has explanations based on technological innovation (for instance, the impact of internet and other modern information and communication technologies and on competitiveness, the business 
model being the way how the organization gains a competitive advantage. In this last case the business model is the result of a strategy, but itself does not represent a strategy (Boons and Lüdeke-Freund, 2013).

Integrating the requirements of sustainable development in business administration is a complex and difficult process. Although the proposed concept have rational explanations and correlated with the explicative models that reveal the plurality in the value concept's interpretation, their acceptability is limited and then they are used, especially in periodic company reports, they are used without rigorous checking of significances. However, in the speciality literature the content of these concepts is clarified even if divergence persists regarding certain aspects.

\section{Sustainability Strategies in Businesses}

The particular configuration internal and external factors restrains the possibilities of each company for integrating sustainability becoming necessary a decision regarding the most appropriate way for integrating sustainability, respectively of choosing the most suitable sustainability strategy.

The correlation of sustainability strategy with the business strategy provides the most simple therewith most used typology. Hence, it is differentiated the strategy of risk avoidance; the strategy of efficiency (cost reduction by increasing efficiency in the use of materials and energy); and the differentiation strategy. Each of these strategies involves innovation, but the importance of innovation for the success of the strategy is different. The first two categories aim the same goal of minimizing costs, while the third one is using sustainability as a means of differentiation.

The risk avoidance strategy is most often a reaction to external criticism on the behalf of consumers, investors, or potential customers. The company has to prove that it knows the issue and it involves in reducing the risks related to sustainability at the level of both enterprise and suppliers. For the implementation of this strategy there are used mainly the certifications for complying with internationally recognized standards. A particular case is represented by suppliers' management especially for companies that are acting of the retail market, manufacturing products that incorporate a great variety of materials accruing from more countries. The typical reaction of these companies is social responsibility and publication of periodical reports with sustainability indicators.

Companies could decide aiming a higher performance level than legal compliance or the one imposed by customers by anticipating the evolution toward increased restrictiveness of standards. Product and process innovation could be necessary for reaching the desired performance level, while the benefits of such reaction could be observable along with the evolution of standards toward the expected direction.

By the efficiency strategy it is aimed the smart use of natural resources and human capital leading to cost reductions. Such a strategy could envisage both internal and suppliers' processes.

Within a highly competitive environment numerous companies identify a strategic advantage in increasing energy efficiency and efficiency of resource use. The main goal of such strategy is cost reduction, the decision alternative being, most frequently, the relocation of production in countries where costs are lower. 
Increasing efficiency involves cost reduction by the diminishment of energy and material consumption but it could bring other types of savings such as reducing expenses for storage, waste management, filtering pollutants etc. The potential for cost reduction by this sustainability strategy is high enough. For instance, $3 \mathrm{M}$ company saved 1.4 billion $\$$ for 34 years by implementing the program Pollution Prevention Pays (3P); company GE Industrial made annual savings of 12.8 million $\$$ by using economic bulbs; a subsidiary of Alcoa reduced water consumption by $80 \%$ in this way saving up to 40 thousands $\$$ /year (Seebode et all, 2012).

At the extent that efficiency gains are determined by innovations such companies could also direct toward the market of clean technologies where they could trade their technological solutions. The incomes obtained on these markets could be large enough to avoid cost reduction by relocation.

As long as human capital is regarded, this strategy supposes a powerful motivation of the staff. The means for accomplishing this are responsibility boosting policies and profit redistribution, advantageous working conditions, stability, involvement etc.

The differentiation strategy is based on the need of the company to distinguish itself from the competitors. Sustainability themes that are most often used for this purpose are climate change, food security, transparency of decision making, demographic ageing, rising of digitalization, exhaustion of natural resources, health in relation with nature, transportation of fossil fuels etc. (table 2.1).

Table 1: Top 10 of themes addressed by sustainability activists in 2014

\begin{tabular}{|c|l|}
\hline Crt.nr. & Themes \\
\hline 1 & Climate change \\
\hline 2 & Transparency by request \\
\hline 3 & How to feed a planet with a growing population \\
\hline 4 & Fracking - the fear from unknown \\
\hline 5 & Online intimacy - who watch the watcher? \\
\hline 6 & Arctic - the next battle field \\
\hline 7 & Water - the last drop \\
\hline 8 & Trains, trucks, tancks, pipes - the disturbing transport of fossil fuels \\
\hline 9 & SOS Health - reconnecting with our food \\
\hline 10 & Forest eyes - palm oil, deforestation and human rights \\
\hline
\end{tabular}

Source: Woblgemuth, E., Klei, K. (2013). Stakeholders activism 2014: The top 10 issues likely to drive global campaigns towards brands. Sustainable Brands Webinar-Future 500.

Selecting the sustainability topic is an important decision. This will take in account the characteristics of the product/service, by also the possibilities of transforming them or the value they have for the consumer/beneficiary.

The differentiation strategy could be regarded as a strategy that continuously solves a problem with permanently changing coordinates. The possibility of adopting such strategy depends very much on innovation, respectively on the existing potential for creating new products/services. This potential could be enhanced by collaborating with associations, groups of users, NGOs, local authorities etc. for designing sustainable products/services.

The elements of this typology are also found in the classification of corporate social 
responsibility strategies. In their case, there were outlined (Gănescu, 2012):

- Passive strategies (defensive): enterprises reject any form of ethical responsibility that is not in accordance with their economic interests, excepting the ones that are already integrated in legal norms; operationally, such enterprises ensure compliance with legal provisions;

- Reactive strategies: enterprises recognize the ethical responsibility in relation with the main stakeholders and react than these signal incompliant situations;

- Proactive strategies: enterprises recognize the ethical responsibility in relation with stakeholders and initiate actions for minimizing the negative impact.

Other criteria used for the analysis of sustainability strategies are the dimension of sustainable development that is approached and the company function. Thus, there are strategies for addressing social problems and strategies for environmental problems, respectively strategies regarding distribution and supply chain, creation of competitive advantage, increasing of financial performance.

In relation with the plan in that the change is made and the actions initiated toward it there are the following categories (Bocken et all, 2014):

- Strategies based on changes in the technological plan by actions that are aiming:

- Maximization of material and energy efficiency: low carbon footprint technologies, LEAN manufacturing processes; additive manufacturing; dematerialization; enhanced functionality; clean technologies;

○ Valuing waste: industrial symbiosis, after-use taking over, extended responsibility of the producers;

o Replacement of natural resources used in product manufacturing: use of sustainable energy, wood, bio-plastic;

o Reducing the use of toxic and dangerous substances: organic agriculture; manufacturing products without heavy metals etc.

- Strategies based on changes on social plan by actions pursuing:

o Priority supply of functionality for avoiding product procurement: product-service systems (PSS) that could be oriented toward products (extended guarantee), use (lending, leasing, shared use) or toward result (services for toxic and dangerous waste removal);

o Discouraging consumption: consumer education, demand management, limited availability, increased longevity of products;

- Strategies based on changes on organization plan by actions toward:

o Redefining business in relation with social and/or environmental goals: social enterprises, valuation of local resources, flexible work program;

o Business models that could be applied on larger scales: collaborative approaches, business incubators, innovation platforms.

Sustainability strategies could be differentiated also by the dynamic of integration process. Thus there are distinguished the following categories (Rankin et all, 2014):

- Strategies that secure legal compliance regarding working conditions and environmental protection;

- Profitability driven strategies: social and environmental aspects are considered according to the demonstrated contribution of their solving to the increasing of profit by improving image, maintaining of licence etc.; changes are consisting in cost reductions by 
marginal improvements, without involving investments;

- Innovative strategies: these grant an equal importance to economic, social and environmental aspects; changes consists in increasing efficiency, innovation, formalization of sustainability evaluation criteria, and intensification of stakeholder communication;

- Strategies based on organizational change: the organizational structure and the business model are optimized and sustainability is considered an important condition for the long term development of the business; actions that are initiated exceed the limits of the enterprise being oriented toward suppliers and other partners from the collaborative network;

- Strategies with impact on the society (societal), named also transformative sustainability strategies: consider sustainability as a component of the core-business; the main motivation is to serve society; are willing to redefine their selves and the nature of the business and the competitive context by integrating sustainability on the business agenda; the effects of their actions exceed the limits of the enterprise and of the stakeholders, consisting in creation of new markets and local development partnering with NGOs.

Another typology of sustainability strategies takes in account what is changed, how the change could be made and the purpose of the change, for each of these criteria a three level sustainability greed being applied as it is represented in table 2.2.

Table 2: Sustainability strategy typology by the level of integration

\begin{tabular}{|l|l|l|l|}
\hline Types & Problems (What?) & $\begin{array}{l}\text { Organizational } \\
\text { perspective (How?) }\end{array}$ & Value added (For what?) \\
\hline Business as usual & Economic problems & Interior-exterior & Share value \\
\hline $\begin{array}{l}\text { Level } 1 \text { sustainable } \\
\text { business }\end{array}$ & $\begin{array}{l}\text { Problems on three } \\
\text { dimensions }\end{array}$ & Interior-exterior & Share value \\
\hline $\begin{array}{l}\text { Level } 2 \text { sustainable } \\
\text { business }\end{array}$ & $\begin{array}{l}\text { Problems on three } \\
\text { dimensions }\end{array}$ & Interior-exterior & Triple bottom line \\
\hline $\begin{array}{l}\text { Level } 3 \text { sustainable } \\
\text { business }\end{array}$ & Sustainability challenges & Exterior-interior & $\begin{array}{l}\text { Value added for the } \\
\text { common good }\end{array}$ \\
\hline Key changes & Widening of concerns & Perspective & $\begin{array}{l}\text { Diversification of value } \\
\text { added }\end{array}$ \\
\hline
\end{tabular}

Source: Muff, K., Dyllick, T. L. (2015). An organizational roadmap of Business Sustainability. Organization and environment, February.

The level 1 sustainable business secures the increase of share value by valuing opportunities and managing risks occurring for the three dimensions economic, social, and environmental. On the second level, sustainable business supposes the management of the triple bottom line, respectively a process in that companies manage their risks, obligations, and financial, social, and environmental opportunities. At the third level of business sustainability, also mentioned as the genuine sustainable business, it is reached the change of the perspective. Thus, it is occurring the passing from negative impact minimization to the understanding of a significant positive impact could be created in relation with the rations of sustainable development. At this level business administration firstly assess the environment in what it will operate and attempts outlining responses for the question: what can be done for solving the critical problems of the moment using the 
available competences and resources (Muff and Dyllick, 2015).

The great variety of sustainability strategies in businesses suggests on the one hand the existence of numerous opportunities, and on the other hand a high interest on the behalf of businesses in identifying opportunities and accelerating societal change.

\section{Conclusions}

The theoretical knowledge regarding sustainability in businesses provides a great variety of concepts that surprise different aspects. The most important feature of sustainable business is the fact that it recognizes the multi-dimensional character of the value. Hence, the sustainable business creates economic, social, and environmental value and for each of these there are quite precise possibilities of quantification.

Integrating sustainability into businesses is a priority recognized at global scale, but meeting this demand is an important decision. According to the existing possibilities and the intensity of the pressure, there are adopted different sustainability strategies, the most known categories being the strategies for risk avoidance, efficiency, and differentiation. Implementing these strategies may use a variety of managerial tools (management systems, corporate social responsibility, communication strategy, methods for sustainability performance assessment), being obvious the emergence of a market of sustainability consultancy that facilitates the use of these.

\section{References}

Allee, V. E. R. N. A., Schwabe, O. (2011). Value Networks and the true nature of collaboration. Digitial edition edn. ValueNetworks, LLC.

Bilsen, V., Rademaekers, K. (2009). Study on the Competitiveness of the EU eco-industry. Within the Framework Contract of Sectoral Competitiveness Studies-ENTR/06/054. Final Report-Part, 1.

Boons, F., Lüdeke-Freund, F. (2013). Business models for sustainable innovation: state-of-the-art and steps towards a research agenda. Journal of Cleaner Production, 45: 9-19.

Bocken, N., Short, S., Rana, P., Evans, S. (2013). A value mapping tool for sustainable business modelling. Corporate Governance, 13(5): 482-497.

Bran, F., Ioan, I., Rădulescu, C.V. (2013). Verde devine culoarea afacerii de succes, Calitatea - acces la succes, 14 (134), pg. 113-116.

Bran, F., Rădulescu, C.V., Ioan, I., Popa, C. (2011). Sinergii globale în direcția protecției mediului. Editura Universitară. București.

Brundtland, G., Khalid, M., Agnelli, S., Al-Athel, S., Chidzero, B., Fadika, L., ... \& Okita, S. (1987). Our Common Future ('Brundtland report').

Gănescu, M.C. (2012). Responsabilitatea socială a întreprinderii ca strategie de creare şi consolidare a unor afaceri sustenabile. Economie teoretică şi aplicată, XIX (11): 93-109.

Globescan (2012). Financial Short-Termism a Major Obstacle to Sustainable Change in Business: Expert Poll, http://www.globescan.com/commentary-and-analysis/press-releases/press-releases2012/84-press-releases-2012/189-financial-short-termism-a-major-obstacle-to-sustainable-changeinbusiness-expert-poll.htm, accesat la 10.04.2015.

Ludeke-Freund, F. (2010). Towars a conceptual framework of business models for sustainability, R. Wever, J. Quist, A. Tukker, J. Woudstra, F. Boobs, N. Beute (eds.), Knowledge collaboration and learning for sustainable innovation, Delft.

Moore, S.B., Manring, S.L. (2009). Strategy development in small and medium sized entreprises for sustainability and increased value creation. Journal of Cleaner Production, 17: 276-282.

Muff, K., Dyllick, T. L. (2015). An organizational roadmap of Business Sustainability. Organization and environment, February. 
Mustață, R.V., Bonaci, C.G., Hintea, C., Neamțu, B. (2013). Educaţie de afaceri pentru dezvoltare sustenabilă: cazul universităților românești, Amfiteatru economic, XV (7s): 556-573.

Nidumolu, R., Prahalad, C. K., \& Rangaswami, M. R. (2009). Why sustainability is now the key driver of innovation. Harvard business review, 87(9), 56-64.

Rankin, A., Gray, A. W., Boehlje, M. D., \& Alexander, C. (2011). Sustainability strategies in US agribusiness: Understanding key Drivers, objectives, and actions. International Food and Agribusiness Management Review, 14(4): 1-20.

Robèrt, K. H., Schmidt-Bleek, B., De Larderel, J. A., Basile, G., Jansen, J. L., Kuehr, R., Wackernagel, M. (2002). Strategic sustainable development-selection, design and synergies of applied tools. Journal of Cleaner production,10 (3): 197-214.

Rojanschi, V., Bran, F., Grigore, F., Ioan, I. (2006). Cuantificarea dezvoltării durabile, Editura Economică, București, pg.18.

Seebode, D., Jeanrenaud, S., \& Bessant, J. (2012). Managing innovation for sustainability. R\&D Management, 42(3): 195-206.

Sinkovics, N., Sinkovics, R. R., Yamin, M. (2014). The role of social value creation in business model formulation at the bottom of the pyramid-Implications for MNEs?. International Business Review, 23(4): 692-707.

Yunus, M., Moingeon, B., Lehmann-Ortega, L. (2010). Building social business models: lessons from the Grameen experience. Long range planning, 43(2): 308-325. 